\begin{tabular}{|c|c|c|c|}
\hline KULTURA & \multicolumn{2}{|c|}{$\begin{array}{l}\text { POLSKA AKADEMIA NAUK } \\
\text { KOMITET SOCJOLOGII } \\
\text { INSTYTUT STUDIÓW POLITYCZNYCH }\end{array}$} & ISSN 0023-5172 \\
\hline SPOLECLF & 2018, nr 1 & GENEALOGIA PODZIAŁÓW & \\
\hline
\end{tabular}

PIOTR KOPIEC

Katolicki Uniwersytet Lubelski

\title{
PROJEKT RADYKALIZACJI REFORMACJI: ULRICHA DUCHROWA TEOLOGICZNA KRYTYKA WSPÓŁCZESNEGO PORZĄDKU SPOŁECZNEGO I POLITYCZNEGO*
}

Kościół Ewangelicki w Niemczech (Evangelische Kirche in Deutschland, EKD), największa instytucja skupiająca niemieckie wspólnoty ewangelickie, wciąż jest istotnym aktorem niemieckiego życia politycznego i społecznego, mimo postępującej sekularyzacji społeczeństwa. Jednym z wielu obszarów jego aktywności jest interpretacja współczesnych zjawisk i procesów społecznych oraz formułowanie ich ocen w perspektywie teologii ewangelickiej, co znajduje wyraz w publikowaniu tzw. memorandów (Denkschriften). Katalog tematów poruszanych w tych opracowaniach jest bardzo szeroki: od kwestii ekologicznych przez związane $z$ etyką seksualną i postępem medycznym po funkcjonowanie instytucji państwowych i społecznych, jak edukacja czy służba zdrowia.

W ostatnich latach coraz istotniejszym zagadnieniem podejmowanym przez teologów ewangelickich jest krytyka ekonomicznej globalizacji i wolnorynkowego kapitalizmu. Choć oficjalne wypowiedzi Kościoła są nieco powściągliwe, to nietrudno zauważyć, że znaczna część aktywnych ewangelików darzy sympatią poglądy alterglobalistyczne czy lewicowe, przy czym lewicowość należy rozumieć jako nacisk na aktywne i refleksyjne kształtowanie instytucji społecznych i ekonomicznych, a więc również jako odrzucenie paradygmatu wolnego rynku jako naturalnego regulatora aktywności gospodarczej. Wśród wielu autorów o takim podejściu szczególne miejsce należy przyznać Ulrichowi Du-

Adres do korespondencji: petrko@kul.lublin.pl

* Publikacja finansowana w ramach programu Ministerstwa Nauki i Szkolnictwa Wyższego pod nazwą Narodowy Program Rozwoju Humanistyki w latach 2016-2019 (nr umowy: 0101/NPRH4/H26/83/2016). 
chrowowi, który od wielu lat formułuje bardzo ostrą krytykę kapitalizmu, prowadzoną z pozycji chrześcijańskiej i posiłkowaną argumentacją skrypturystyczną, historycznoteologiczną, a także socjologiczną i politologiczną. Popularność Duchrowa czyni z niego kogoś w rodzaju ewangelickiego rewolucjonisty, a jego wypowiedzi znajdują bardzo szeroki oddźwięk społeczny, co odzwierciedlają liczne komentarze, nawiązania i inspiracje polityczne. Środowisko skupione wokół niemieckiego teologa staje się ewangelickim think-tankiem przyczyniającym się do rozwoju myśli lewicowej.

Duchrow występuje przeciwko kapitalizmowi, zwłaszcza przeciw tej jego zglobalizowanej (zarówno w sensie geograficznym, jak i społecznym) formie, którą ustrój ten przybrał współcześnie. Kwestionuje samo sedno natury kapitalizmu, który — zdaniem niemieckiego teologa — zasadza się na uznaniu osoby ludzkiej za istotę z natury nienasyconą i egoistyczną (homo oeconomicus), przez co ex definitio instrumentalizującą każdą wspólnotę. Wychodząc od krytyki kapitalizmu, dokonuje oceny kondycji współczesnych społeczeństw zachodnich, określonych $z$ jednej strony przez społeczną atomizację, a z drugiej przez kategoryzacje prowadzące do wykluczenia społecznego jednostek i całych grup. Jest to więc społeczeństwo podzielone i jest to kultura oparta na podziałach i pogłębiająca te podziały. W obliczu powszechnie odczuwanego kryzysu społecznego szczególną rolę w jego rozwiązywaniu Duchrow przypisuje teologii i kościołom chrześcijańskim, ale poddanym teologicznej reinterpretacji. Podkreśla, że misją chrześcijan jest odzyskanie znaczenia i siły oddziaływania pawłowego stwierdzenia „Nie ma Żyda ani Greka” (Ga 3,28), tak aby kościoły wyprowadzały społeczeństwa ze schematu wykluczenia, które dziś staje się zasadą ich funkcjonowania. Służy temu zwłaszcza program radykalizacji reformacji, który opiera się na aktualizacji i częściowym odwróceniu założeń teologii reformacyjnej, zwłaszcza na podkreśleniu znaczenia usprawiedliwienia oraz wolności chrześcijańskiej dla wydobywania się z uwarunkowań kulturowych i politycznych.

Zamierzam tu przedstawić podstawowe diagnozy kryzysu społecznego, które formułuje niemiecki teolog, oraz zwięzłą analizę promowanego przez niego modelu społecznego i gospodarczego. Szczególną wagę przywiązuje on do idei „radykalizacji reformacji” (Die Reformation radikalizieren), polegającej na wykorzystaniu obchodów pięćsetlecia reformacji, aby ponownie odkryć potencjał tkwiący w postulatach Marcina Lutra i odnieść je do aktualnej kondycji kultury i społeczeństwa. Omawia listę 94 tez, które stanowią - naturalnie w nawiązaniu do 95 tez Lutra - podsumowanie i etykietę tego programu radykalizacji. Realizacja tych celów powinna wypełnić istotną lukę w odkrywaniu źródeł współczesnej niemieckiej myśli politycznej. Warto wspomnieć, że wiele tez Duchrowa wzbudza duże kontrowersje, przyczynia się to jednak do jego popularności. Propozycje niemieckiego teologa dotyczące reinterpretacji podstawowych założeń teologii reformacyjnej, tak aby stała się ona inspiracją do kształtowania społeczeństwa o potencjale niwelowania podziałów, mogą być 
istotnym — mimo swej kontrowersyjności — głosem w dyskusji nad genealogią podziałów toczących współczesne społeczeństwa.

\section{EUROPEJSKA TEOLOGIA WYZWOLENIA}

Duchrow jest określany mianem teologa wyzwolenia. Trzeba jednak dodać, że jego interpretacja teologii wyzwolenia jest specyficzna, aplikowana do europejskich warunków konsumpcyjnego społeczeństwa europejskiego. Warto przypomnieć, że ten nurt teologiczny wciąż wymaga systematyzacji, etykieta "teologia wyzwolenia” odnosi się bowiem do różnych kierunków, niekiedy dość odległych od siebie. Andrzej Pietrzak (2013, s. 89) omawia jej podstawowe znaczenia i przypomina, że definicje tego pojęcia podlegają typologizacji w zależności od kontekstu i miejsca powstania oraz podnoszonych postulatów, jest ona jednak głęboko powiązana $z$ latynoamerykańskim kontekstem. Spośród wielu typologii można przytoczyć taką, w której wyróżnia się cztery główne nurty:

„1) teologię wyzwolenia w kontekście działań pastoralnych Kościoła [...]; 2) teologię wyzwolenia biorącą za punkt wyjścia zaangażowanie rewolucyjne Latynoamerykanów [...]; 3) teologię wyzwolenia koncentrującą się na zjawisku ucisku i wyzwolenia w dziejach Ameryki Łacińskiej [...] (z najważniejszym jej przedstawicielem Gustavo Gutiérrezem); 4) [...] teologię wyzwolenia jako dyscyplinę akademicką — która akcentuje historyczno-kulturowe doświadczenie w tym względzie (Leonardo Boff)".

Istotą teologii wyzwolenia jest odniesienie chrześcijańskiego orędzia do konkretnego kontekstu społecznego i kulturowego Ameryki Łacińskiej z uznanymi za niesprawiedliwe strukturami ekonomicznymi i politycznymi. Idee sprawiedliwości i odpowiedzialności społecznej, postępu społecznego oraz likwidacji ubóstwa znajdują $\mathrm{w}$ niej bardzo silne teologiczne zakorzenienie. „W pastoralnej teologii wyzwolenia opcja na rzecz ubogich i inne opcje pastoralne nie są ahistorycznym głoszeniem prawd i zasad, lecz są wyrazem autentyzmu Kościoła w Ameryce Łacińskiej, a zwłaszcza poważnego podejścia do istniejących problemów i powierzonej mu przez Jezusa Chrystusa misji" (Pietrzak 2013, s. 92).

Bardzo celnym podsumowaniem istoty teologii wyzwolenia jest krótkie streszczenie myśli Gustavo Gutiérreza zawarte w przedmowie do jego książki The Power of the Poor in History: „Gutiérrez — pisze Robert McAfee Brown (1986, s. viii) - ujmuje teologię uprawianą przez Północ jako próbę odpowiedzi na pytania osób niewierzących, tych, dla których w świecie nowoczesnym, wiara stała się trudna z powodu Oświecenia, nowoczesnej nauki czy technologii. Takie pytania są przede wszystkim natury intelektualnej. Ale w okolicznościach, w których żyje Gutiérrez, pytania stawiane są przez tych, którzy są «nie-osobami», ludźmi marginalizowanymi, przez tych, dla których nie ma miejsca w społeczeństwie, którzy są odepchnięci od odpowiedzialności pełni egzysten- 
cji ludzkiej”. Dla peruwiańskiego teologa rozważenie egzystencjalnej i społecznej sytuacji staje się więc punktem wyjścia do refleksji teologicznej.

Trywialne jest stwierdzenie, że teologia wyzwolenia stała się źródłem wielu kontrowersji, zwłaszcza te jej nurty, które otwarcie nawiązywały do marksizmu i uznawały rewolucję za dopuszczalny mechanizm zmiany niesprawiedliwych stosunków społecznych. Kościół katolicki podczas pontyfikatu Jana Pawła II wyraźnie skrytykował te podejścia w Libertatis Nuntius z 1984 roku: „Wprawdzie zasługą teologii wyzwolenia jest odkrycie na nowo wartości ważnych tekstów prorockich i Ewangelii, występujących w obronie ubogich, jednakże dochodzi przy tym do szkodliwego utożsamienia ubogiego z Pisma Świętego i proletariatu w rozumieniu Marksa. Doszło w ten sposób do wypaczenia chrześcijańskiego rozumienia ubogiego, a walka o prawa ubogich przekształca się w starcie pomiędzy klasami w ideologicznej perspektywie walki klasowej. Kościół ubogich oznacza więc Kościół klasowy, który uświadomił sobie wymogi walki rewolucyjnej jako etapu prowadzącego do wyzwolenia i celebrującego to wyzwolenie

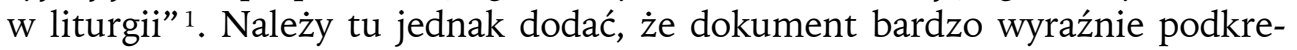
śla niejednorodność teologii wyzwolenia, akcentując, że w jej obrębie istnieją nurty często sprzeczne wobec siebie.

Duchrow krytykę formułowaną przez Watykan widzi inaczej. Odnosi ją do zabiegów sił politycznych kapitalizmu, zwłaszcza administracji rządowej Stanów Zjednoczonych. Przytacza definicję teologii wyzwolenia zawartą w tzw. II dokumencie amerykańskiego Komitetu z Santa Fe z 1988 roku: „Jest to doktryna polityczna ukrywająca się pod przybraniem wyznania religijnego, mająca wydźwięk antypapieski i antywolnorynkowy, aby ograniczać niezależność społeczeństwa kontrolą państwa" (Roncallo 2014, s. 35), i przypomina, że komitet ten jednoznacznie wiąże teologię wyzwolenia z marksizmem i komunizmem, uznając, że są to „idee mniej chrześcijańskie niż komunistyczne” (Elliott 2006, s. 15).

Czym w takim razie jest europejska teologia wyzwolenia? Duchrow jej wyjaśnienie wyprowadza z luterańskiej teologii wolności. Dla reformatora wolność jest podstawowym darem i jednocześnie przymiotem chrześcijanina, co wyraża w słynnej antynomii zawartej w jednym $z$ najważniejszych jego pism $O$ wolności chrześcijanina: „Chrześcijanin jest całkowicie wolnym panem wszystkich rzeczy, nikomu niepodległym” oraz "chrześcijanin jest najuleglejszym sługą wszystkich rzeczy i wszystkim podległy". Zestawienie to jest zrozumiałe oczywiście dopiero w pełnym kontekście luterańskiej antropologii, w której usprawiedliwienie dane darmo w sposób zdecydowany określa pozycję człowieka w świecie i w której wyprowadzona jest wyraźna granica między człowiekiem zewnętrznym i wewnętrznym, cielesnym i duchowym, żyjącym w obietnicy Ewangelii i żyjącym jednocześnie w ziemskiej rzeczywistości grzechu. Wolność jest

1 „Instrukcja o niektórych aspektach teologii wyzwolenia” (https://ekai.pl/dokumenty/instruk cja-o-niektorych-aspektach-teologii-wyzwolenia-libertatis-nuntius/ [28.12.2017]). 
więc właściwie zrozumiała jedynie w kontekście wiary; dobrze ilustruje to cytat przypisywany Lutrowi, umieszczony na belce nośnej ściany wittenberskiego uniwersytetu: „Nic nie zależy ode mnie, ale chcę odpowiedzieć na Słowo Boże radosnym sercem i pełną ufnością, do czego Bóg obdarzył mnie radosnym i nieustraszonym Duchem" (2017).

Wolność, o której mówi Luter, ma więc charakter teologiczny. Choć teoria społeczna reformatora, $z$ twierdzeniem o dwóch królestwach oraz nauką o urzędach i powołaniu, była raczej konserwatywna, to jednak podkreślanie wolności jako podstawowego przymiotu chrześcijanina dawało potencjał różnorodnym dążeniom do emancypacji. We współczesnym ewangelicyzmie to wewnętrzne powiązanie wolności i emancypacji staje się inspiracją idei, podejść i strategii rozwijanych przez Kościoły, również przez EKD. Podejście to można więc określić jako paradygmat tworzony przez pojęcia wolność-wyzwolenie-emancypacja, $z$ całym ich semantycznym bagażem i przy uwzględnieniu różnych perspektyw, do których się odnoszą.

Duchrow jest $\mathrm{w}$ awangardzie teologów uznających takie rozumienie wolności, której dotyczy, według niego, najważniejsze przesłanie płynące z Pisma Świętego. Opierając się na szczegółowej analizie skrypturystycznej bardzo stanowczo stwierdza, że teologia chrześcijańska musi być teologią wyzwolenia, w przeciwnym razie nie jest chrześcijańska. Stwierdzenie to ilustruje kluczowymi dla historii zbawienia fragmentami biblijnymi (Duchrow 2011, s. 69 i nast.). Identyfikacja ta musi mieć charakter dynamiczny, to znaczy teologia musi tak interpretować Boże Słowo, aby miała moc zmieniania rzeczywistości.

Kombinując tę ewangelicką interpretację pojęcia wolności z podstawowymi znaczeniami teologii wyzwolenia, Duchrow wyprowadza kluczowe aspekty jej europejskiej wersji. Przede wszystkim konieczne jest odniesienie się do schematu bogata Północ-biednie Południe, po który tak chętnie sięgają różne organizacje alterglobalistyczne. Jego uwzględnienie, biorąc $w$ nawias zakres związanego z nim uogólnienia, tworzy kontekst niezbędny do nakreślenia różnic między europejską a południowoamerykańską teologią wyzwolenia. Przede wszystkim Europa musi zawrócić z drogi cywilizacji konsumpcyjnej, która niszczy społeczeństwa i środowisko naturalne, opierając się na chciwości i egoizmie. Duchrow przywołuje tu pojęcie cywilizacji biedy (die Zivlilisation der Armut), opisane przez Hansa-Petera Gensichena pod znaczącym tytułem Armut wird uns retten (Bieda nas uratuje): „Cywilizacja biedy, bazująca na materialistycznym humanizmie przeobrażonym inspiracjami chrześcijańskimi, odrzuca akumulację kapitału jako przyczynę sprawczą historii i posiadanie bogactwa jako zasadę humanizacji; zasadą rozwoju czyni powszechne zaspokojenie potrzeb, a fundamentem humanizacji wzrost wzajemnej solidarności" (Hans-Peter Gensichen 2009, s. 35, cyt. za: Duchrow 2011, s. 70). Taka definicja pomaga odnieść różne kierunki teologii wyzwolenia do globalnego Południa i globalnej Północy. O ile dla Południa wyzwolenie oznacza wydostanie się wszechobecnej biedy, niesprawiedliwości i dyskryminacji, tak aby powszechnie zostały zaspo- 
kojone podstawowe potrzeby, o tyle Północy chodzi o wyzwolenie do postawy mniejszych potrzeb, „o wyzwolenie-do-mniej” (Hans-Peter Gensichen 2009, s. 35, cyt. za: Duchrow 2011, s. 71). Wyzwolenie dla Południa nie jest więc prostym odrzuceniem naśladowania drogi Północy, prowadzenia polityki rozwoju czy podążania za konsumpcyjnym stylem życia. Wyzwolenie dla Północy natomiast nie ogranicza się do postulatu przemiany wartości, ale jest bezwzględną koniecznością, warunkiem sine qua non dalszego trwania europejskiej cywilizacji w obliczu ekologicznej katastrofy i kryzysu społecznego. Ten drugi polega przede wszystkim na powiększającej się rozpiętości między bogatymi i biednymi również w państwach Północy, na kurczeniu się klasy średniej i zjawisku, które Duchrow określa jako narastającą biedę psychiczną i społeczną, a które można podsumować jako poszerzanie się obszarów społecznego wykluczenia. Wyzwolenie musi więc odnosić się do wszystkich warstw społecznych, ale przede wszystkim do tych, którzy z różnych względów znajdują się poza głównym nurtem społecznym. Ostatecznie drogą do wyzwolenia jest afirmacja postawy „stawania się mniejszym” (das Wenigerwerden), która musi być reprezentowana i promowana przez świadomych tego kryzysu i która ma przeciwdziałać rozpowszechnionemu wzorowi nienasyconej konsumpcji i bogactwa. Naturalnie Duchrow zbliża się tu do różnych krytyków społeczeństwa konsumpcyjnego, takich jak David Loy (1997, s. 279), Zygmunt Bauman czy Jean Baudrillard. W odróżnieniu jednak od nich wyraźnie wskazuje aktora społecznego odpowiedzialnego za promowanie nowych wzorów - ma nim być społeczny ruch wyzwolenia (Befreiungsbewegung) — sojusz wykluczonych i tych, którzy są z nimi solidarni. W ruchu tym musi uczestniczyć Kościół, a raczej Kościoły chrześcijańskie, a instrumentów oddziaływania ma dostarczać rozwijana przez nie europejska teologia wyzwolenia.

Jej fundamentem ma być zatem integralny związek praktyki społecznej i lektury biblijnej, a jej locus theologicus ma stanowić walka prowadzona wewnątrz ruchu wyzwolenia o trwałe, społeczne i ekonomiczne, sprawiedliwe struktury określające warunki życiowe (Duchrow 2011, s. 75). Jednak zestawiając zadanie przypisane europejskiej teologii wyzwolenia z własną diagnozą kondycji kościołów europejskich, zwłaszcza w Niemczech, Duchrow zajmuje stanowisko zdecydowanie krytyczne. Krytyka ta dotyczy przede wszystkim niewielkiego uczestnictwa Kościołów w opisanym powyżej ruchu wyzwolenia, niedostatecznego udziału tzw. zwykłych chrześcijan (grassroots Christians) w procesie władzy w obrębie Kościołów, a także na przykład braku odpowiedniego miejsca dla teologii wyzwolenia jako subdyscypliny w programie edukacji teologicznej. Zdaniem niemieckiego teologa, pozycja europejskich Kościołów jest zupełnie inna niż południowoamerykańskich, gdzie można zaobserwować daleko idącą współpracę hierarchii kościelnej z laikatem.

Duchrow krytykuje również niewielkie uczestnictwo niemieckich Kościołów w ruchu ekumenicznym, zwłaszcza w Światowej Radzie Kościołów. Chodzi przede wszystkim o programy przezwyciężenia strukturalnej, kulturowej i eko- 
nomicznej przemocy, rozwijane przez tę największą organizację ekumeniczną, takie jak „Sprawiedliwość, pokój i integralność stworzenia” (Justice, peace and integrity of creation), program powołany na VI Zgromadzeniu Ogólnym ŚRK w 1983 roku w Vancouver (zob. Niles 1992, s. 82 i nast.). Warto zaznaczyć, że zarówno Światowa Rada Kościołów, jak i Światowa Federacja Luterańska czy Światowa Wspólnota Kościołów Reformowanych, a więc organizacje skupiające Kościoły wyrosłe na tradycji, odpowiednio, luterańskiej i kalwińskiej, już od ponad dwudziestu lat aktywnie uczestniczą w pracach różnych organizacji ruchu alterglobalistycznego, jednoznacznie krytykując kapitalistyczny porządek i neoliberalną globalizację (Kopiec 2016). Wspierają na przykład prace Światowego Forum Społecznego, zarówno recenzując jego działania, jak i inspirując poszczególne grupy tworzące to forum. Należy dodać, że w wymienionych ekumenicznych i ponadkościelnych organizacjach interpretacje porządku społecznego opierają się na krytyce antropologii homo oeconomicus, która przedstawia, ich zdaniem, obraz człowieka jako istoty z natury nienasyconej i egoistycznej (Mshana, Peralta 2010, s. 99). W ich ocenie taka wizja człowieka leży u podstaw neoliberalnego systemu ekonomiczno-społecznego, w którym skuteczność i zysk określają dominujące systemy aksjologiczne.

Duchrow wyodrębnia dwie główne przyczyny niewielkiego znaczenia i nikłej recepcji europejskiej teologii wyzwolenia w Kościołach europejskich. Pierwsza to ich nieadekwatna odpowiedź na obowiązujący w zachodniej nowoczesności paradygmat nieograniczonego postępu naukowego i technologicznego. Zdaniem niemieckiego teologa, przez stulecia nie sformułowały one konstruktywnej krytyki opanowania wszystkich obszarów życia przez kapitalistyczną gospodarkę i wiedzę racjonalno-techniczną (Duchrow 2011, s. 75). Druga przyczyna, mocno powiązana z pierwszą, to „pokonstantyński” model dopasowywania się Kościoła do panujących struktur politycznych, do dziś kształtujący eklezjalny krajobraz Europy (Duchrow 2011, s. 75).

Analizując krytykę Duchrowa, skierowaną przede wszystkim do jego macierzystego Ewangelickiego Kościoła w Niemczech, trzeba powiedzieć, że zamyka on oczy na wiele działań, które EKD podejmuje, tak w perspektywie wewnętrznej, jak i zewnętrznej. Dobrą ilustracją tej aktywności jest masowa mobilizacja ewangelickich parafii w sytuacji kryzysu migracyjnego, co znajduje wyraz w licznych oddolnych akcjach, jak na przykład umieszczanie grup uchodźców w domach parafialnych, lekcje języka niemieckiego prowadzone przez członków parafii i wiele innych ${ }^{2}$. Zarzuty niemieckiego teologa są kierowane raczej do instytucjonalnego Kościoła i to mimo że EKD i tak w wielu kwestiach stawia się raczej po lewej stronie myśli politycznej. Lewicowość ta jest jednak, co już zostało zaznaczone, bardziej widoczna, kiedy spogląda się na Kościół na poziomie

2 Przykładem są inicjatywy prowadzone $\mathrm{w}$ ewangelickich parafiach $\mathrm{w}$ Kolonii; na podstawie rozmowy z Dr Hansem-Georgiem Linkiem, emerytowanym referentem ekumenicznym Ewangelickiego Kościoła w Kolonii (20 kwietnia 2017 r.). 
parafialnym, a zwłaszcza na poszczególne kręgi liderów i aktywistów politycznych. W bardzo jaskrawy sposób przejawia się to w inicjatywie „Radykalizacja reformacji”, w którą zaangażowały się środowiska teologów ewangelickich i do której w znacznym stopniu przyczynił się Ulrich Duchrow. Stanowi ona niejako egzemplifikację koncepcji europejskiej teologii wyzwolenia.

\section{WSPÓŁCZESNA REFORMACJA RADYKALNA}

Obchody pięćsetlecia reformacji przetoczyły się przez świat, a inicjatywy i akcje podejmowane w ich ramach trudno zliczyć. Większość $z$ nich miała charakter religijny i ekumeniczny, choć nie brakowało — również w Polsce — odniesień politycznych i kulturowych, skoncentrowanych zwłaszcza na historycznej analizie określanych przez reformację czynników tożsamościowych. Na tym tle wyraźniej widać podejście do reformacji jako dynamicznego procesu, który ma za zadanie zmieniać rzeczywistość w kierunku uznanym za pożądany w świetle teologicznego imperatywu Królestwa Bożego. Jednym z najważniejszych wyrazów takich działań jest sformułowanie 94 tez w ramach wspomnianego projektu „Zradykalizować reformację — prowokowaną przez Biblię i kryzys". Twórcy ruchu sięgając po formę listy tez, w oczywisty sposób nawiązują do symbolicznego początku reformacji, jakim było opublikowanie 95 tez Lutra, ale widoczny jest też paradygmat ecclesia reformata et semper reformanda („kościół reformowany i stale się reformujący"), charakterystyczny dla teologii reformowanej (kalwińskiej). Charakterystyczny jest również ilustrujący stronę internetową projektu slogan zamieszczony na na najbardziej znanym portrecie Lutra: „Nie zawsze przybijam jakieś rzeczy do drzwi kościelnych, ale kiedy to robię, zaczyna się ruch". Należy dodać, że chodzi o ruch społeczny i religijny, którego uczestnicy dążą do wykorzystania idei reformy zastanych struktur myślowych, aby umożliwiło to wyłonienie się bardziej pokojowego i sprawiedliwego społeczeństwa.

Tezy opublikowane przez ruch radykalnej reformacji dobitnie ukazują żarliwość, z jaką skupione wokół projektu środowisko teologów i liderów kościelnych podejmuje swoją refleksję. Wśród ponad czterdziestu sygnatariuszy można zauważyć podpisy osób z całego świata i z różnych Kościołów, widoczne są też nazwiska autorów zaangażowanych w ruch ekumeniczny i alterglobalistyczny, również w projekty Światowej Rady Kościołów. Charakterystyczne jest też to, że bardzo szeroko reprezentowane są Kościoły z krajów położonych raczej na peryferiach światowego systemu politycznego. Ich odmienne doświadczenia i wrażliwość są wyczuwalne w treści programu.

Podczas analizy treści tez uderza ich rzeczywiście rewolucyjny charakter, przy czym rewolucyjność ta odnosi się właściwie do wszystkich obszarów refleksji: teologicznej, socjologicznej czy filozoficznej. Autorzy opracowania uznają, że obecna epoka to kairos transformacji, to czas, w którym konieczne jest podważenie pojęciowego i aksjologicznego fundamentu cywilizacji. 
Duchrow większość wypowiedzi dotyczących natury naszej cywilizacji rozpoczyna od przedstawienia pewnej historiozoficznej periodyzacji epoki, którą - jak stwierdza bardzo dobitnie - określają dwa słowa kluczowe: pieniądze i chciwość. Nie jest tu możliwe dokładne zreferowanie głównych punktów historycznego rozwoju wyodrębnionych przez niemieckiego teologa, warto jednak odnieść się do dwóch istotnych poczynionych uwag. Pierwsza jest porównaniem kapitalizmu do faszyzmu, co w zamierzeniu ma być jaskrawą ilustracją ostrza krytyki kapitalistycznego porządku światowego, druga dotyczy zbadania zależności między rozwojem kapitalizmu a reformacją jako koniecznego wprowadzenia do wytłumaczenia podstawowego znaczenia programu radykalizacji reformacji. Niektóre inne twierdzenia brzmią nieco osobliwie i po raz kolejny dowodzą, jak rewolucyjne jest myślenie Duchrowa i skupionego wokół niego środowiska.

Kapitalizm i faszyzm są, jego zdaniem, wytworem jednej historii. Przypomina $\mathrm{w}$ tym kontekście chwytliwe zdanie Johana Galtunga, założyciela Instytutu Badań nad Pokojem w Oslo: „nazizm to zachodnia cywilizacja w swoim ekstremum" (Duchrow1986, s. 149). Tak jak faszyzm przyniósł miliony ofiar, tak też kapitalizm jest obciążony śmiercią milionów ludzi w wyniku klęsk głodu po drugiej wojnie światowej. Aby porównanie uczynić bardziej jaskrawym, Duchrow cytuje zdanie Jeana Zieglera (2012): „Dziecko, które dzisiaj umiera $z$ głodu, to dziecko zamordowane". Tak jak faszyzm opierał się na myśleniu afirmującym skuteczność, tak też kapitalizm, przyjmując za swój cel wzrost gospodarczy, instrumentalizuje człowieka i całe społeczeństwa jako narzędzie osiągania wyabstrahowanych zamierzeń. Oba, faszyzm i kapitalizm, narzucaja sposoby myślenia mechanicznego, redukując ośrodki myśli alternatywnej i wymuszając bezrefleksyjne postawy. Implikuje to kolejną analogię — wspólny obu totalitaryzm, zarówno w aspekcie politycznym, jak i kulturowym, przy czym kapitalizm można określić jako totalitaryzm epistemologiczny, skoro przedstawiany jest jako samouzasadniający się system, dla którego nie ma alternatywy. Duchrow przyznaje jednocześnie, że jest to totalitaryzm o wiele bardziej ukryty, subtelny i zawoalowany, oparty na zinternalizowanej logice zysku (niemiecki teolog pisze o Geldlogik - logice pieniądza), od której trudno jest uciec we współczesnym społeczeństwie. Tłumaczy to bierność w obliczu powiększających się nierówności społecznych oraz bardzo skromną liczebność środowisk, które sprzeciwiają się obecnemu porządkowi polityczno-ekonomicznemu.

W awangardzie sprzeciwu wobec totalitaryzmu logiki zysku Duchrow widzi część chrześcijańskich Kościołów i organizacji ponadkościelnych. Odnosi się do kilku oficjalnych deklaracji, które w ostatnich latach zostały uchwalone przez różne instytucje. Przypomina Wyznanie z Akry z 2004 roku (Accra Confession), dokument Światowej Wspólnoty Kościołów Reformowanych, którego autorzy w punkcie dziewiętnastym bardzo wyraźnie proklamują: „[...] mówimy nie obecnemu światowemu porządkowi gospodarczemu, który został nam narzucony przez neoliberalny kapitalizm globalny" (Conradie 2010, s. 57); przy- 
wołuje zaadaptowaną w 2012 roku przez Światową Radę Kościołów deklarację $z$ São Paulo (The São Paulo Statement. International Financial Transformation for the Economy of Life): „Odrzucamy porządek gospodarczy, który opiera się na chciwości i nadmiarze ofert konsumenckich, i jesteśmy świadomi tego, jak bardzo neoliberalny kapitalizm prowadzi nasz umysł ku temu, aby ciągle pragnąć więcej" (Mshana, Peralta 2010, s. 101). Wreszcie, odnosi się do treści adhortacji Evangelii Gaudium papieża Franciszka (2013, s. 52-60), który jako śródtytuły rozdziału poświęconego wyzwaniom współczesnego świata umieścił następujące sformułowania: „ «Nie» dla ekonomii wykluczenia”; , «nie» dla nowego bałwochwalczego pieniądza”; „«nie» dla pieniądza, który rządzi, zamiast służyć”; „ «nie» dla nierówności społecznej rodzącej przemoc”.

Wykorzystując kościelny fundament, niemiecki teolog zwraca uwagę na obchody pięćsetlecia reformacji i proponuje, aby wykorzystać je do zreinterpretowania idei reformacji w nowym kontekście, w którym przyszłość świata jest zagrożona przez panujący porządek społeczno-ekonomiczny. Propozycja ta poparta jest refleksją nad rolą teologii protestanckiej w procesie utrwalania tego porządku.

Duchrow w swych licznych opracowaniach zamieszcza analizy dotyczące historii porządku, który nazwał „cywilizacją pomnażania pieniądza” (Geldvemehrungszivilisation). Narodziny tej cywilizacji były związane z dokonującą się około trzech tysięcy lat temu profesjonalizacją sił militarnych i związanym z tym wprowadzeniem pieniądza. Z kolei organizowanie życia ekonomicznego i społecznego wokół pieniądza doprowadziło do formowania się i stopniowego rozprzestrzeniania myślenia i postaw opartych na kalkulacji.

Warto tu przynajmniej pokrótce odnieść się do podejścia Lutra wobec wyłaniającego się nowożytnego kapitalizmu. Max Weber w słynnej tezie o zależnościach między kapitalizmem a etyką protestancką główne miejsce przyznał Kalwinowi - genewski reformator przez swą naukę społeczną i antropologię przyczynił się do rozwoju społeczeństwa nowożytnego, zorganizowanego wokół republikańskiej myśli politycznej i kapitalizmu jako systemu gospodarczego. Luter zaś był konserwatystą politycznym, obrońcą starego porządku opartego na współdziałaniu monarchii i Kościoła. Duchrow przywołuje te poglądy wittenberskiego teologa, które uznaje za odnoszące się do natury kapitalizmu. Najpierw, nieco przekornie, przypomina tezę 27, która zawiera krytykę słynnego ówczesnego sloganu pomocnego przy sprzedaży odpustów: „Ludzkie brednie opowiadają ci, którzy głoszą, że gdy grosz w skrzynce zabrzęczy, dusza z czyśćca uleci”. Dla Duchrowa sformułowanie to nie tylko jest sygnałem krytyki pewnej praktyki, ale odsłania nastawienie Lutra do pieniądza i opartej na nim ideologii. Kluczowe tutaj są jednak inne fragmenty pism reformatora, przede wszystkim ten z komentarza do pierwszego przykazania z Dużego Katechizmu (1999, s. 62 i nast.): „Niejeden myśli, że ma Boga i dość wszystkiego, gdy posiada pieniądze i mienie; buduje na tym $i$ chełpi się $z$ tego tak niewzruszenie i pewnie, iż nie dba o nic innego. Zaiste, taki ma także Boga, który się nazywa 
mamoną - to jest pieniądz i mienie, którym oddaje całe serce. Mamona jest najpospolitszym bożyszczem tego świata. Kto ma pieniądze i mienie, ten czuje się pewnie, bywa wesoły i nieustraszony, jak gdyby był w raju; i przeciwnie, kto ich nie ma, czuje się niepewnie i trapi się, jak gdyby nie wiedział o żadnym Bogu". Duchrow uznaje, że w tym fragmencie Luter wyraża przekonanie, że pieniądz i jego pomnażanie są najbardziej rozpowszechnionym cieniem religii; to obserwacja, którą kilkaset lat później Walter Benjamin określił: „kapitalizm jako religia" (zob. Hoffmann 2015, s. 117). W komentarzu do siódmego przykazania zaś grupy trudniące się szeroko pojętym lichwiarstwem i spekulacją reformator nazywa "rozległą stajnią pełną wielkich złodziejów” (Duży Katechizm 1999, s. 85).

Jak zauważa Hoffmann (2015, s. 117) fakt, że Luter był krytykiem rodzącego się kapitalizmu, został dostrzeżony już przez Marksa. Dla reformatora porządek ekonomiczny i społeczny oparty na akumulacji kapitału był zaprzeczeniem porządku bożego. Lichwiarze zaś (Wucherer) zostali przezeń nazwani dosadnie - największymi mordercami na ziemi. W konsekwencji, według Duchrowa, teolog wittenberski może stać się inspiratorem dla nowej, radykalnej reformacji, która zmieni kapitalistyczny porządek współczesnego świata.

\section{TEZY — PROJEKT DLA WSPÓŁCZESNOŚCI?}

Analizę treści 94 tez warto rozpocząć przytoczeniem - mimo rozmiarów in extenso - wprowadzenia sformułowanego przez jego autorów:

„Marcin Luter rozpoczął swoje 95 tez z 1517 roku wezwaniem Jezusa do nawrócenia: «nawracajcie się, bo bliskie jest królestwo Boże». Pięćset lat później żyjemy w czasie, który, tak jak biblijny «rok jubileuszowy», również przynagla do nawrócenia i przemiany ku sprawiedliwym stosunkom. Nie mówimy tego w przeciwieństwie do kościoła rzymskokatolickiego i zakorzenionych w nim ruchów wyzwolenia, ale w przeciwieństwie do struktur imperium, które obecnie panuje. Tylko we wsłuchaniu się w słowa $z$ krzyża $(1$ Kor 1,18$)$ i w westchnienia umęczonego stworzenia, tylko kiedy otworzymy nasze uszy na krzyk ofiar u dołów naszego hiperkapitalistycznego porządku światowego, jubileusz reformacji może stać się wyzwalającym rokiem jubileuszowym. Chrześcijańskie samousprawiedliwienie, która umacnia ten system, stoi w sprzeczności z reformacyjnym usprawiedliwieniem przez wiarę. Usprawiedliwienie można zaś przeżywać tylko w inkluzywnej solidarności. Jesteśmy teolożkami i teologami, w przeważającej mierze luterańskimi, ale też i reformowanymi, mennonickimi, anglikańskimi i metodystycznymi, którzy połączyli się w tym wciąż trwającym projekcie, aby na nowo przemyśleć biblijne korzenie i współczesne wyzwania myśl reformacyjnej. Niepohamowane zniszczenie ludzkiego, jak i nie-ludzkiego życia, w świecie, który znajduje się pod totalitarną dyktaturą pieniądza i chciwości, rynku i wyzysku, wymaga radykalnego zwrotu ku biblijnym nakazom, jak to było na początku reformacji. Obowiązujący system gospodarczy, wspierany przez panujące imperialne aparaty władzy, wyprzedaje ziemię, ludzi i przyszłość naszych dzieci. 
Tak nasze kościoły i wspólnoty, jak i poszczególni chrześcijanki i chrześcijanie, $\mathrm{w}$ wielu miejscach urządzili się w swym społecznym status-quo i stracili swą krytyczno-profetyczną moc protestów, oporu i przemiany. Sprawiedliwość Boża z łaski jest oddzielona jest od społecznej sprawiedliwości i jak «zwietrzała sól» (Mt 5,13) nie jest już używana. Jest jakaś fałszywa droga teologii reformacyjnej, z której musimy zawrócić - z Lutrem, ale i przeciwko Lutrowi. Reformacja może stać się dzisiaj na nowo kairosem transformacji" (Duchrow 2015, s. 25 i nast.) ${ }^{3}$.

Lista tez została ułożona tematycznie, choć poszczególne tematy na siebie zachodzą. Tworzą one bloki przedzielone wprowadzającymi cytatami biblijnymi. Taka struktura to również nawiązanie do tez Lutra, w ich kompozycji też można było wyróżnić pewne bloki. W treści tez słowem kluczowym jest „reformacja”, przy czym pojęcie to odnosi się zarówno do historycznego procesu rozpoczętego pięć wieków temu, jak i do konieczności reinterpretacji tego procesu dziś. Tezy są krytyką błędnych, w mniemaniu autorów, kierunków, w jakich poszedł protestantyzm i całe chrześcijaństwo, a także afirmacją samego pojęcia reformacji, uwalniającego dynamikę wiary chrześcijańskiej do wyzwolenia człowieka i społeczeństw z opresji i zagrożeń. Ponieważ treść tez jest bardzo bogata i wielowątkowa, w skróconym opracowaniu konieczne jest ograniczenie się do wybranych wątków w nich poruszonych.

Autorzy rozpoczynają od mocnego uderzenia, które zostaje zawarte w bloku pierwszych czterech tez. Przyjmują, że kluczowym celem jest antropologiczna zmiana wydobywająca znaczenie biblijnego usprawiedliwienia człowieka $z$ ograniczeń rozumienia augustyńsko-anzelmiańskiego, w którym odnosi się je do grzechu pierworodnego i przebaczenia. Przyjmują, że zwłaszcza w teologii pawłowej grzech jest powiązany z konkretną polityczną organizacją imperium rzymskiego, $\mathrm{w}$ konsekwencji też usprawiedliwienie - i wyzwolenie ma swe bardzo głębokie ziemskie, horyzontalne znaczenie - emancypacji od wszelkich grzesznych struktur światowych tworzących niewolę, biedę i niesprawiedliwość. Usprawiedliwienie oznacza więc wyzwolenie, a teologia ma za zadanie uświadamiać, że wolność jest podstawowym darem, który został dany człowiekowi. W konsekwencji człowiek wierzący musi mieć świadomość wolności i musi dążyć do wolności, stając się jednocześnie przykładem dla wszystkich tkwiących w niewoli, czy to politycznej, czy społecznej czy psychicznej.

Blok drugi (tezy 5-23) zawiera znaną z pism Duchrowa krytykę kapitali$z m u$, zorganizowaną $\mathrm{w}$ dwóch odsłonach. Po pierwsze, zostaje nakreślony obraz współczesności, pogrążonej w niesprawiedliwych stosunkach społecznych i ekonomicznych oraz w głębokim kryzysie ekonomicznym. Taki stan dzisiejszego świata jest konsekwencją „panowania pieniądza” i nieprzerwanej od kil-

3 Lista tez jest dostępna na stronie internetowej: http://www.radicalizing-reformation.com/ index.php/de/ (strona w dwóch wersjach językowych [15.01.2018]). Dalsza analiza będzie oparta na tezach zamieszczonych na tej stronie, $w$ związku z czym kolejne odniesienia nie będą podawane. 
kunastu wieków stopniowej indywidualizacji własności i zrywania wspólnoty. W bardzo skrótowy sposób można powiedzieć, że logika diagnozy zawartej w tezach przywodzi na myśl schemat Wielkiej Transformacji opisanej przez Karla Polanyiego. Po drugie, zostaje wykazane, że współczesny porządek gospodarczy i społeczny głęboko zaprzecza orędziu biblijnemu. Paradygmat wzrostu napędzający ten porządek narusza określone przez Biblię zasady życia społecznego, kieruje się bowiem logiką konkurencyjności i skuteczności, co niszczy podstawy wspólnoty. Poza tym nadrzędność wzrostu niszczy naturalne środowisko, co z kolei sprzeciwia się nakazowi, by człowiek „uprawiał i strzegł” Eden $(\operatorname{Rdz} 2,15)$.

Biblia przekazuje drogę ekonomii „wystarcza” dla wszystkich (Ökonomie des Genug). Ponieważ antropologia biblijna zasadza się na obrazie człowieka stworzonego na obraz i podobieństwo Boże, konsekwencją takiego rozumienia jest równość i godność każdej kobiety i każdego mężczyzny. Przenosząc takie ujęcie antropologiczne na poziom społeczny, zakłada się zasadę solidarności społecznej. Poza biblijnym odniesieniem tezy zawierają też interpretację reformacyjnej nauki społecznej, zwłaszcza jej fundamentalnego wezwania człowieka do odczytania siebie jako współpracownika Boga i do uczestniczenia w życiu społecznym, gospodarczym i politycznym, aby budować jego sprawiedliwe, solidarne i odpowiedzialne struktury. W tym miejscu autorzy tez formułują krytykę teologii protestanckiej, która w historycznym rozwoju nie tworzyła sprawiedliwego porządku społecznego, ale wręcz uzasadniała i teologicznie legitymizowała niesprawiedliwe struktury (teza 19).

Kolejny blok (tezy 24-32) rzuca głębokie wyzwanie zakorzenionej w scholastyce teologii ofiary, uznanej za wykrzywiającą obraz Boga. Albowiem rozumienie śmierci Chrystusa na krzyżu jako zadośćuczynienia za popełnione przez ludzkość grzechy prowadzi do ujmowania Boga jako „sadystycznego, sprawiającego cierpienie władcy" (teza 24). Interpretując śmierć Jezusa na krzyżu należy zawsze zestawiać ją z jego zmartwychwstaniem. Zwycięstwo nad śmiercią jest jednocześnie sądem nad przemocą i wyrazem sprawiedliwości oraz solidarności Boga z wszystkimi, którzy cierpią w wyniku struktur zła. Teologia krzyża staje się w ten sposób teologią życia.

Teologiczne rozważania bloku trzeciego wprowadzają w blok czwarty, poświęcony krytyce społeczeństwa konsumpcyjnego i jego konsekwencji dla środowiska naturalnego (tezy 33-46). Ponownie początek stanowi refleksja teologiczna: cały świat powinien być rozważany jako rzeczywistość sakramentalna. W konsekwencji przyjęcie Ewangelii oznacza przyjęcie zobowiązania, aby troszczyć się o integralność stworzenia, i to na poziomie zarówno osobistych decyzji i postaw, jak i zabiegów o nową politykę gospodarczą, społeczną i ekologiczną (teza 39). Autorzy przywołują tu tendencje konsumpcjonizmu, który, oparty na dążeniu do coraz większego posiadania, nie liczy się z kosztami ponoszonymi przez środowisko naturalne oraz relacje społeczne. Akcentują, że dążenia, aby „żyć w zbytku” (leben im Überfluss), nie można sprowadzać do nieograniczo- 
nego podsycania pragnień, ale że należy zbytek ten rozumieć $\mathrm{w}$ perspektywie „równowagi pomiędzy wszelkimi zależnościami” (teza 40). Choć nie przytacza się wprost pojęcia zrównoważonego rozwoju (sustainable development), to jednak wezwanie do troski o kolejne pokolenia przywołuje na myśl właśnie podstawową definicję tego terminu.

Blok piąty (tezy 47-57) zawiera bardzo zdecydowaną krytykę jakiejkowiek przemocy („nie istnieje żadna droga, za pomocą której można byłoby uzasadnić przemoc"), a jako lustrzane odbicie tej krytyki rozwija teologiczne uzasadnienie dążenia do pokoju. Przemoc nie jest tu rozumiana jako jakieś wyizolowane z porządku społecznego abstrakcyjne pojęcie, ale dobitnie określana jako brak pokoju. Inaczej mówiąc, gdy nie dąży się do pokoju, powstaje przemoc. W konsekwencji - chrześcijanie są powołani do tego, aby praktykować pokój, w każdym aspekcie, żyjąc, mówiąc i działając w pokoju i dla pokoju (teza 55). Oznacza to również aktywne dążenia do przeciwstawiania się wszelkim praktykom przemocy, zarówno na poziomie lokalnym, jak i globalnym, instytucjonalnym oraz nieformalnym. Autorzy tez zwracają szczególną uwagę na pewne rodzaje przemocy, wymierzonej przeciw konkretnym kategoriom grup dyskryminowanych bądź wykluczonych. Dlatego piszą o krzyku współczesnych ofiar przemocy domowej, wyzysku ekonomicznego, naruszania praw człowieka, niesprawiedliwości wobec stworzenia, imperializmu i wojny. Sformułowania i treść tej części nadają jej bardzo mocny charakter polityczny, choć są solidnie zakorzenione skrypturystycznie.

Szósty, przedostatni blok (tezy 58-76) jest najobszerniejszy, a zarazem najważnieszy. Obok krytyki oraz reinterpretacji teologii protestanckiej zawiera jej ocenę z perspektywy programu radykalnej reformacji. Rozpoczyna się od bardzo zwięzłego wprowadzenia $\mathrm{w}$ podstawowe zasady teologii luterańskiej: sprawiedliwość Boża jest miłosiernym skierowaniem Boga do bezbożnych (sola gratia) i jako zaufanie w Bożą wierność w wierze (sola fide) w Chrystusa (solus Christus). W kolejnych tezach znajdują się odniesienia do uniwersalizmu w teologii św. Pawła i konieczne sprostowania pewnych luterskich jej interpretacji.

Na początek autorzy akcentują, że Ewangelia oznacza historyczną i całkowitą zmianę relacji społecznych. Chrześcijaństwo dostarcza wzorów, w jaki sposób budować rzeczywistość, w której kategorie prowadzące do społecznego wykluczenia tracą swoje uprawomocnienie (nie ma Żyda ani Greka...) (Ga 3,28). Jednak w celu odzyskania siły tego wzoru niezbędna jest reinterpretacja znaczeń, jakie Luter przypisywał dialektycznemu zestawieniu prawa i usprawiedliwienia. Problemem nie jest sama opozycja prawa i usprawiedliwienia, ale fakt, że zestawienie to posłużyło do wykluczającej identyfikacji — Izrael i Kościół katolicki zostali uznani za społeczeństwa prawa, w przeciwieństwie do Kościołów poreformacyjnych, które określały siebie jako społeczeństwo usprawiedliwienia. W ten sposób teologia usprawiedliwienia utraciła swe właściwe przeznaczenie, którym było proklamowanie prawdy o chrześcijańskim zbawie- 
niu i wyzwoleniu, stała się jedynie czynnikiem tożsamości wyznaniowej. Radykalna reformacja musi więc zmierzać do nowego rozumienia prawa i usprawiedliwienia, w którym prawo jest traktowane jako służebne wobec człowieka i społeczeństwa. Prawo jest konieczne, aby utrzymać wspólnotę (usus politicus), ale wobec społeczeństwa ma funkcję służebną. Jeżeli staje się narzędziem opresji albo gwarantem utrwalania niesprawiedliwych stosunków władzy, to chrześcijanie wręcz mają obowiązek wypowiedzieć mu posłuszeństwo i dążyć do jego zmiany. Potencjał takiej zmiany wynika z usprawiedliwienia, które staje się udziałem chrześcijan i którego inherentnym wymiarem jest wyzwolenie, ujęte również horyzontalnie - jako wydobywanie się ze społecznej niesprawiedliwości i w konsekwencji społecznego wykluczenia.

Ostatni blok tez (tezy 77-94) kreśli program działania dla Kościoła z perspektywy radykalnej reformacji. Jest to rozdział najbardziej radykalny w wymowie i w konsekwencji najbardziej kontrowersyjny. Również tu autorzy dokonują reinterpretacji podstawowych treści teologii luterańskiej. Po pierwsze, definiują Kościół za Wyznaniem Augsburskim jako wspólnotę świętych, w której wiernie głosi się Ewangelię i właściwie administruje sakramentami, ale jednocześnie odrzucają jego instytucjonalizację. Kościół realizuje się więc niejako tam, gdzie chrześcijanie gromadzą się na nabożeństwie. Po drugie, przypominając zasadę kapłaństwa powszechnego, uznają, że o ile w czasach Lutra demokratyzowała ona Kościół, o tyle dziś powinna być rozumiana jako wezwanie chrześcijan do walki o uniwersalne prawa obywatelskie oraz sprawiedliwy podział dóbr. Po trzecie, Kościół nie powinien koncentrować się na indywidualnej pobożności wiernych, ale na działalności społecznej. Po czwarte wreszcie, teologowie powinni opracować nowy język, za pomocą którego w dzisiejszym społeczeństwie przedstawiać się będzie prawdy ewangeliczne. Tezy kończą się odniesieniem do Dietricha Bonhoeffera, jednego z najważniejszych teologów protestanckich XX wieku, który widział przyszłość Kościoła jako wybranej i ekskluzywnej grupy naśladowców Chrystusa, trwających przy ludziach opuszczonych i cierpiących.

Radykalna reformacja, którą proponuje Ulrich Duchrow, jest jednym z wielu teologicznych podejść sformułowanych we współczesnej wewnątrzchrześcijańskiej debacie nad kondycją społeczeństw i kultury zachodniej. Jest też jednak podejściem szczególnym, co przejawia się właśnie w stopniu radykalizacji proponowanej przez niemieckiego teologa interpretacji podstawowych treści teologii protestanckiej. Wykorzystuje on swoją interpretację do sformułowania programu, który w zamierzeniu rozbudzałby świadomość konieczności rewolucyjnych przemian w światowym porządku społeczno-gospodarczym. Nie pretendując do teologicznej oceny treści tego programu muszę stwierdzić, że Duchrow z pewnością bardzo twórczo wykorzystuje pojęcia wypracowane przez 
szesnatowieczną reformację, wprowadzając je we współczesny kontekst historyczny. Pozostaje sprawą dyskusji, czy jego diagnozy są adekwatne i jaki jest potencjał proponowanych przez niego rozwiązań. Mimo wszystko jest to zapewne ciekawa propozycja, otwierająca drzwi do nowych sposobów myślenia teologicznego, wykorzystująca obficie refleksję społeczną i znajdująca wielu odbiorców oraz zwolenników. W konsekwencji jest ważnym elementem współczesnego protestantyzmu oraz może stanowić czynnik rozwoju społeczeństwa obywatelskiego w skali globalnej.

\section{BIBLIOGRAFIA}

Conradie Ernst, 2010, Globalization, Consumerism, and the Call for a Status Confessionis, w: Allan Boesak, Len Hansen, Globalization II. Global Crisis, Global Challenge, Global Faith. An Ongoing Response to the Accra Confession, Sun Press, Bloemfontain.

Duchrow Ulrich, 1986, Weltwirtschaft heute - ein Feld für bekennende Kirche?, Kaiser Verlag, München.

Duchrow Ulrich, 2011, Brauchen wir eine europäische Befreiungstheologie? Alternativen zum marktliberalen Verständnis von Freiheit aus dem Geist des Evangeliums, w: Uwe Beyer, Facetten der Freiheit. Evangelischer und säkularer Freiheitsbegriff in der Spannung gesellschaftlicher Wirklichkeit. 5 Jahre evangelische Stadtakademie Aachen, Mainz.

Duchrow Ulrich, 2015, Befreiung zur Gerechtigkeit, LIT Verlag, Berlin.

Duży Katechizm, 1999, w: Księgi Wyznaniowe Kościoła Luterańskiego, Augustana, Bielsko-Biała.

Elliott Neil, 2006, Liberating Paul: The Justice of God and the Politics of the Apostle, Fortress Press, Minneapolis.

Gensichen Hans-Peter, 2009, Armut wird uns retten. Geteilter Wohlstand in einer Gesellschaft der Weniger, Public-Forum, Oberursel.

Hoffmann Martin, 2015, Luther und die Ökonomie. Religionskritik als Kapitalismuskritik, w: Ulrich Duchrow, Martin Hoffmann, Politik und Ökonomie der Befreiung, LIT Verlag, Berlin.

Kopiec Piotr, 2016, Chrześsijańska alterglobalizacja. Światowa Rada Kościołów na rzecz budowy globalnego społeczeństwa obywatelskiego, Wydawnictwo KUL, Lublin.

Loy David, The Religion of the Market, „Journal of the American Academy of Religion”, t. 65, nr 2.

McAfee Brown Robert, 1986, Preface, w: Gustavo Gutiérrez, The Power of the Poor in History, SCM Press, London.

Mshana Robert, Peralta Athena, 2010, Economy of Life. Linking Poverty, Wealth ad Ecology, WCC Publications, Geneva.

Niles D. Preman, 1992, Between the Flood and the Rainbow: Interpreting the Conciliar Process of Mutual Commitment (Covenant) to Justice, Peace and the Integrity of Creation, WCC Publications, Geneva.

Papież Franciszek, 2013, Evangelii Gaudium, Wydawnictwo WAM, Kraków.

Pietrzak Andrzej, 2013, Modele ewangelizacji kultur i inkulturacji wiary w teologii latynoamerykańskiej, Wydawnictwo KUL, Lublin.

Roncallo Alejandra, 2014, The Political Economy of Space in the Americas: The New Pax Americana, Routledge, New York.

Schorlemmer Friedrich, 2017, „Zur Freiheit eines Christenmenschen”, wystąpienie podczas konferencji Międzynarodowej Wspólnoty Ekumenicznej, Wittenberga, sierpień (tekst w posiadaniu autora).

Ziegler Jean, 2012, Wir lassen sie verhungern. Die Massenvernichtung in der Dritten Welt, C. Bertelsmann, München. 


\title{
THE RADICALIZING REFORMATION PROJECT: ULRICH DUCHROW'S THEOLOGICAL CRITIQUE OF THE CONTEMPORARY SOCIAL AND POLITICAL ORDER
}

\author{
Piotr Kopiec \\ (John Paul II Catholic University of Lublin) \\ Summary
}

Ulrich Duchrow is one of the most influential contemporary Protestant theologians. $\mathrm{He}$ is the leader of a movement that describes itself as a radical reformation aiming to use the main principles of Protestant theology for a radical criticism of the contemporary socio-economic order. The author discusses the basic elements of Duchrow's theology, and in particular his formulation of a European theology of liberation. The author also presents the radical reformation project and makes a detailed analysis of its 94 theses, which contain the project's fundamental diagnoses and aims.

Key words / słowa kluczowe

Ulrich Duchrow, Reformation / reformacja, capitalism / kapitalizm, Protestantism / protestantyzm, Evangelical Church in Germany / Kościół Ewangelicki w Niemczech 